\title{
Komi rahvaluulet. Kogunud Paul Ariste
}

Nikolai Kuznetsov

\begin{abstract}
Teesid
Komi ainese on Tartus 1941. ja 1942. aastal komi rahvusest sõjavangidelt kogunud ja üles tähendanud Paul Ariste. Rahvaluulearhiivis talletatud kogu koosneb P. Ariste enese poolt kirja pandud etnograafilistest ja pärimustekstidest. Originaaltekstid on kirjutatud transkriptsioonis ja igale tekstile on lisatud eestikeelne tõlge. Žanriliselt on komi aines üsna mitmekesine, samuti varieerub ulatuslikult tekstide murdekeel. Etnograafiline materjal on kogutud ühelt keelejuhilt. Tekstid on üles kirjutatud nn. Molodtsovi kirjas, mis oli Komimaal levinud 1920. ja 1930. aastatel. Keelejuht on näitlikustanud teksti arvukate joonistega.
\end{abstract}

Märksõnad: Paul Ariste, etnograafia, komi, rahvaluule.

Paul Ariste ei ole käinud komi aladel spetsiaalselt rahvaluulet kogumas. Siiski hoitakse Eesti Kirjandusmuuseumi Eesti Rahvaluule Arhiivis (EKM ERA) tema kogutud komi ainestikku mitmes köites koos teiste soome-ugri rahvaste käsikirjalise materjaliga (vt RKM, Soome-ugri 2, 73-316; RKM, Soome-ugri 3, 9-256; RKM, Soomeugri 9, 1-169 ja RKM, Mitmesugused rahvad, 45-88). Komi aines on kirja pandud Tartus 1941. ja 1942. aastal. Kogutud tekstid pärinevad mitmelt 20-33-aastaselt komi mehelt, kes viibisid Tartus sõjavangina. Paar noormeest olid pärit Permi-Komi rahvusringkonnast, ülejäänud informandid olid tulnud tollase Komi Autonoomse Nõukogude Sotsialistliku Vabariigi (ANSV) erinevatelt murdealadelt. Nende hulgas oli ka üks venelane, kelle kohta P. Ariste teeb märkuse, et ta on käinud sürjani koolis. Naine on sürjalane. Tema hääldus oli siiski veidi venepärane (Komi rahvaluulet 2005: 11). Sellelt noormehelt pärinebki vaid üks pikem tekst. Igalt informandilt on kirja pandud erinev hulk tekste.

Köites RKM, Soome-ugri 2 leidub 244 lehekülge Paul Ariste enda kirja pandud komi rahvaluulet. Originaaltekstid on kirjutatud transkriptsioonis. Igale palale järgneb tõlge eesti keelde. Näiteks võib tuua Afonassei Samkovilt pärit permi-komi mõistatuse:

vunda la, vunda la, vires abu, muna, muna, tui abu? - piž. Lõikan, lõikan, verd ei ole, lähen, lähen, teed ei ole. - Paat (Komi rahvaluulet 2005: 34).

http://haldjas.folklore.ee/tagused/hr28/komi.pdf 
Tõlget ei ole vaid viimasel tekstil (Komi rahvaluulet 2005: 206), mistõttu tundub, et antud kogu on poolik. Kuigi viimane pala kannab numbrit 223, on üleskirjutusi siiski vaid 219 , sest numbrid 141 , 142,143 ja 144 on vahele jäetud. Iga konkreetse teksti või mitme teksti järel on märgitud kirjapaneku koht ja aeg ning esitajaandmed - kas ainult nimi või ka muud andmed, kui informanti mainitakse esimest korda. Kümne viimase pala juures esitajaandmeid küll ei ole, kuid köites RKM, Soome-ugri 9 (vt sellest allpool) on kirjas ka mõned neist kümnest palast koos esitajanimega, mistõttu, arvestades, et need on ühesuguste murdetunnustega, on põhjust arvata, et RKM, Soome-ugri 2 viimased palad pärinevad samalt inimeselt.

Žanriliselt on köite RKM, Soome-ugri 2 materjalid üsna mitmekesised. Siin leidub komi mõistatusi, naljandeid, muistendeid, muinasjutte, tšastuškasid, laule jm. Kuna tekstide esitajad olid pärit erinevatelt aladelt, ei ole ka tekstid keeleliselt ühesugused. Siin on esindatud permikomi ja sürjakomi keele erimurdeid. Mõned näited:

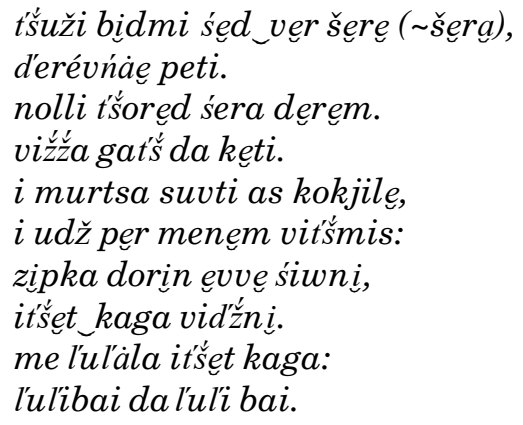

Sündisin, kasvasin musta metsa keskel, läksin külla.

Kandsin kõva kodukootud särki, joonikuid pükse ja kottasid.

Ja alles jäin seisma oma jalule, ja tööd leidus mulle kohe: [pidin] hälli juures oo-oo laulma, väikest last hoidma. 
Ma hällitan väikest last:

l'ul'i bai ja l'ul'i bai (Komi rahvaluulet 2005: 24).

suśe thu suse tho. jeśli kin t'śoža kulas, to sija odžik adži las suśe tholeśs pet'ske.m. - mam viśta las zonkale: en pir t'śasit džodžillas suśettku śojas. suśe tkose šueni i. sija pe e ed'd'en ut'śsiki·k, da kuźjurśi-ja. nillka loas ńeve-sta. sija oinas veta -śas. - talun pe oinas menem suśe tko davi tlis. a sillen dugdị.llis ud'źalni vir.

Sus'etku sus'etko (majavaim). Kui keegi äkki sureb, siis ta näeb enne seda majahaldjat. Ema kõneleb pojale: "Ära mine nüüd ahjutagusesse sahvrisse. Majahaldjas sööb ära.” Majahaldja kohta räägiti, et ta on õige tilluke ja tal on pikad juuksed.

Tüdrukust saab pruut. Ta näeb öösi und. “Täna öösi rõhus mind majahaldjas." Aga tal jäi veri seisma (Komi rahvaluulet 2005: 54, 56).

тедла реліп utka gorze,

kenke kije keke kek;

menam musuk ki.ле лоkte,

vorsigterje gudeken.

Teisel pool jõge prääksub part,

kuskil kuulukse kukkuvat kägu;

minu armsam kuulukse tulevat,

lõõtspilli mängivat (Komi rahvaluulet 2005: 64).

l'on ńetška.n kad.

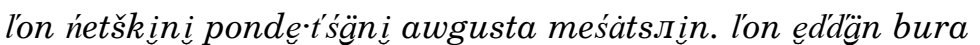
kuźa bindmis. tśsel'àd' t'śukertitśisä l'on тилä, i ponde-tśisä l'on netškin $i$, lon kedija pondis kerni vetšaлaez kośtini lon. kośte’m berśán pondętśisä l'on jur vartлinin. med bur l'on pondisä berinin gosudárstvo ä sitte ts kerni $i$ nańka kerni $i$ t'śet'skom jẹne·sezлä. edd'än bura kerä mijàn l'oniś novjan paśkäm.

Linakitkumise aeg

Lina kitkuma hakatakse augustikuul. Lina kasvas hästi pikaks. Lapsed kogunevad linapõllule ja hakkavad lina kitkuma. Kes hakkas lina kuivatamiseks sarda tegema. Pärast 
kuivatamist hakatakse linu ropsima. Kõige parem lina valitakse riigile sitsi, nankingu ja valgete särkide tegemiseks. Meie linast tehakse õige head rõivad (Komi rahvaluulet 2005: 200).

Mõningaid tekste sellest köitest jõudis Paul Ariste avaldada (vt Ariste 1976: 92-115; 1978: 81-99; 1980: 25-29; 1990: 156-163). Näiteks on ta mitmes Fenno-Ugristica numbris avaldanud 11 sürjakomi teksti Kirill Uljaševilt, kaheksa teksti Kirill Žiževilt, kolm teksti Pavel Kustõševilt ja seitse teksti permikomi keeles Permi-Komi rahvusringkonnast pärit Nikolai Issajevilt. Fenno-Ugristicas avaldatud tekstid on varustatud saksakeelsete tõlgetega. Ülejäänud materjalid ei olnud varem avaldatud.

P. Ariste oli avaldamiseks valmistanud ka muid materjale. Tal on eraldi köitesse RKM, Soome-ugri 9 ümber kirjutatud enamik palasid RKM, Soome-ugri 2-st, samuti juba mainitud Fenno-Ugristicas ilmunud tekstid. See 1943. aastal valminud käsikiri on isegi struktureeritud raamatuna, millel on lühike saksakeelne eessõna ja sisukord. Kõik tekstid on numereeritud ja igal palal on tõlge saksa keelde.

Köite RKM, Soome-ugri 3 komi aines pärineb ainult ühelt inimeselt. Selle kogu ja materjalide esitaja Aleksei Rakovi kohta kirjutab P. Ariste 16. veebruaril 1960:

Komi rahvaluule- ja etnograafiaainestiku on kirja pannud Aleksei Rakov, kes oli pärit Komi ANSV-st Sõktõvdini rajoonist, Õbi külakogust, Jol’i külast.

Märkmed on kirja pandud Tartus. Aleksei Rakov oli sattunud sõjavangi ja pandi tööle AKS-i. Õppisin temalt komi keelt. Noormehel oli keskharidus. Hiljem saadeti ta Lätti laagrisse, kus ta vist hukkunud.

Lisana on üks komi- ja teine venekeelne kiri tema saatuse kohta.

Kogutud materjal on väga väärtuslik (RKM, Soome-ugri 3, 231).

Nende sõnade kirjutamise ajal ei teadnud veel Paul Ariste oma endise keelejuhi tegelikku saatust. Aleksei Rakov on kirjutanud P. Aristele ka kümneid aastaid hiljem juba Komimaalt. Tema kaht kirja aastast 1988 hoitakse Eesti Kirjandusmuuseumi Eesti Kultuuriloolises Arhiivis (EKlA, f 330, m 78:10). A. Rakov kirju- 

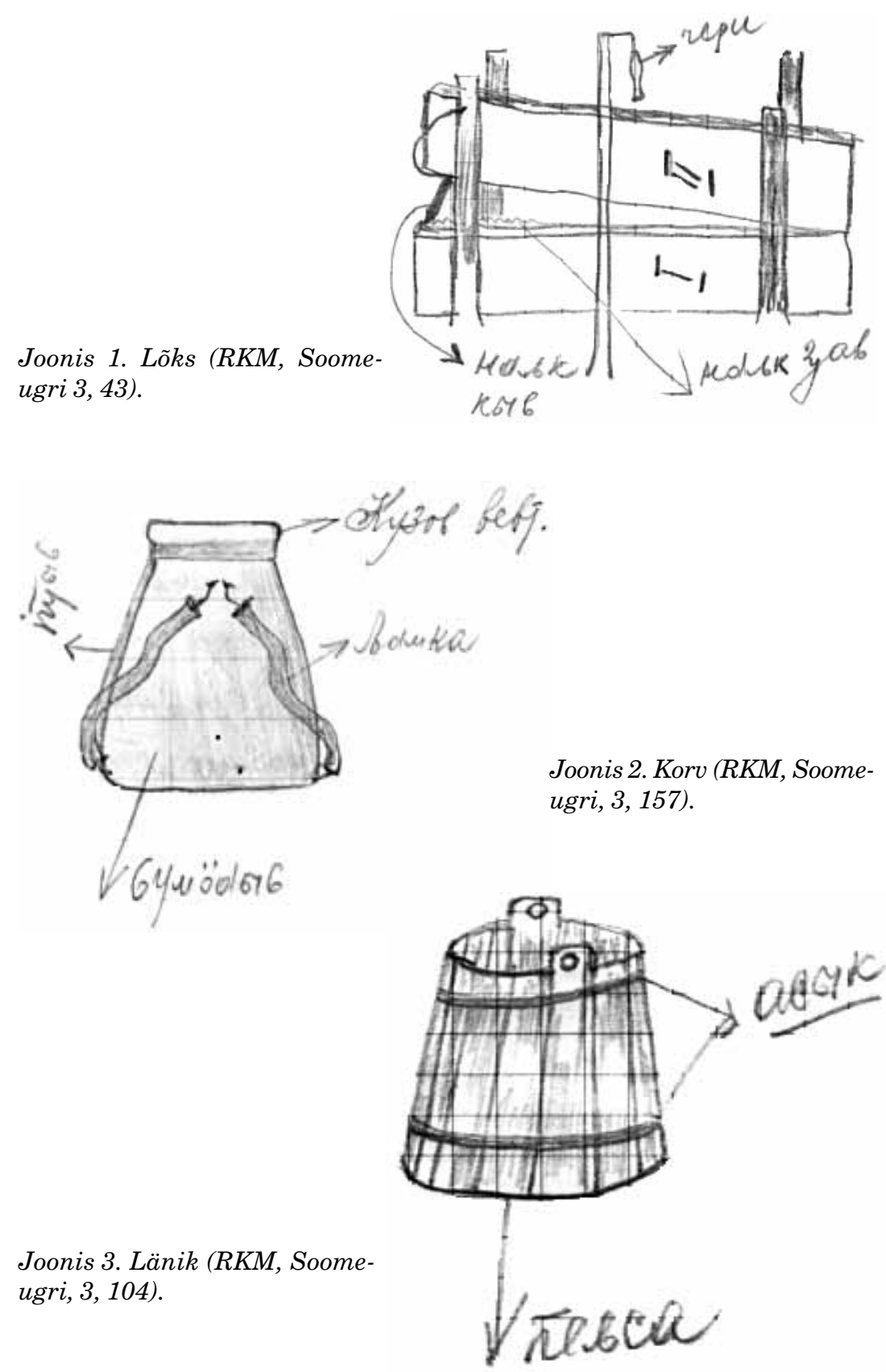
tab, et on naasnud elusana sõjavangistusest koju, kirjeldab oma elu ja tänab P. Aristet headuse eest. Peale nende kirjade on Eesti Kultuuriloolises Arhiivis ka P. Ariste mustandkirjapanekuid komi sõjavangidelt (EKlA, f 330, m 233:2) ja märkmeid A. Rakovi jt tekstidest (EKlA, f 330, m 167:13).

Esimeses vihikus leidub mõningate komi keele grammatika elementide kirjeldusi, komi sõnade tähendusi, mõnede kirja pandud tekstide tõlkeid ja kommentaare. Teises vihikus olevad märkmed on tehtud A. Rakovi (ja ka mõne teise sürjani) keelest A. Rakovi tekstide läbilugemisel.

Aleksei Rakovilt kirja pandud materjal on tõepoolest väärtuslik, seda mitmel põhjusel. Esiteks sisaldab see rohkesti andmeid komide vanemast eluolust. Etnograafiaainestik on väga rikkalik. Andmete esitaja on detailselt kirjeldanud erinevate loomade küttimise viise ja jahiriistade valmistamist, kalastamisvõtteid ja kalurivarustuse valmistamist, põllutöödel, heinategemisel ja majapidamises vajaminevaid tööriistu ja tarbeesemeid, maja ehitamist ja transpordivahendeid, rõivaid ja toiduvalmistamist, mitmesuguseid töid ja lastemänge ning palju muud.

Teiseks on A. Rakov teinud tekstide juurde rohkesti jooniseid, mis on etnograafiliste kirjelduste juures väga tähtis informeeriv faktor. Illustratsioonid on detailsed ja asjalikud.

Kolmandaks on tekstid kirja pandud nn Molodtsovi kirjas ja juba sellepärast on nad uurimisväärsed. Seda kirja kasutati Komimaal aastatel 1918-1932 ja 1934-1936, kui Aleksei Rakov arvatavasti koolis käis. Ilmselt kasutas ta seepärast just seda kirjaviisi, kuigi 1941. aastal polnud see enam kasutusel.

Köites RKM, Mitmesugused rahvad on komi ainet suhteliselt vähe. Enamikku tekstidest ei saa ilmselt pidada päriselt rahvaluuleks ega etnograafiaks, need on pigem informandi kirjapanekud elus juhtunust. Kuid ka siin on midagi muistendi- või muinasjutulaadset. Üks tekst (lk 83-87) on ühe ülalmainitud köidetes esineva teksti kordus. Üks teine tekst (lk 47-48) on A. Rakovi kirja pandud anekdoodi katkend.

Kirjeldatud arhiivimaterjalid pakuvad kindlasti huvi nii folkloristidele ja etnograafidele kui ka lingvistidele, dialektoloogidele ja lihtsalt komi keele ja kultuuri huvilistele. Seda ainestikku tuleb veel uurida põhjalikumalt. 


\section{Arhiiviallikad}

\section{Eesti Rahvaluule Arhiiv}

RKM, Soome-ugri = Eesti TA Fr. R. Kreutzwaldi nim (Riikliku) Kirjandusmuuseumi rahvaluule osakonna rahvaluulekogu, 1995. aasta jaanuari seisuga $445780 \mathrm{lk}$ (peamiselt alates 1945. aastast).

\section{Eesti Kultuurilooline Arhiiv}

EKlA, f 330: Ariste (Berg), Paul (1905-1990) - keeleteadlane, folklorist, 3366 säilikut (1772-1995).

\section{Kirjandus}

Ariste, Paul 1976. Komi-Syrjänisches aus Puzla. Palmeos, Paula et al. (toim). Fenno-Ugristica 2 = Труды по финно-угроведению. Tartu Riikliku Ülikooli toimetised = Ученые записки Тартуского государственного университета = Acta et commentationes Universitatis Tartuensis 382. Tartu: [Tartu Riiklik Ülikool], lk 92-115.

Ariste, Paul 1978. Komi-Permisches aus Gaincovo. Künnap, Ago \& Palmeos, Paula (toim). Fenno-Ugristica 5: Uurali keelte grammatiline ehitus = Труды по финно-угроведению 5: Грамматический строй уральских языков. Tartu Riikliku Ülikooli toimetised = Ученые записки Тартуского государственного университета = Acta et commentationes Universitatis Tartuensis 456. Tartu: [Tartu Riiklik Ülikool], lk 81-99.

Ariste, Paul 1980. Komi-Syrjänisches aus dem Dorfe Nivšera. Fenno-ugristica 7 = Труды по финно-угроведению. Tartu Riikliku Ülikooli Toimetised = Ученые записки Тартуского университета = Acta et commentationes Universitatis Tartuensis 550. Tartu: [Tartu Riiklik Ülikool], lk 25-29.

Ariste, Paul 1990. Komi-Syrjänisches aus dem Dorfe Koni. Fenno-ugristica 16 = Труды по финно-угроведению. Tartu Ülikooli Toimetised = Ученые записки Тартуского университета = Acta et commentationes Universitatis Tartuensis 876. Tartu: [Tartu Ülikool], lk 156-163.

Komi rahvaluulet 2005 = Komi rahvaluulet. Kogunud P. Ariste. Kuznetsov, Nikolai (koost). Tartu: EKM folkloristika osakond. 